Original Article

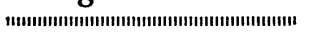

\title{
Photodegradation of the Pyrethroid Insecticide Cypermethrin in Water and on Soil Surface
}

\author{
Naohiro Takahashi, Nobuyoshi Mikami, Tadashi Matsuda \\ and Junshi Miyamoto \\ Laboratory of Biochemistry and Toxicology, Takarazuka Research Center, \\ Sumitomo Chemical Co., Ltd., Takatsukasa, Takarazuka 665, Japan
}

(Received March 30, 1985)

\begin{abstract}
Photodegradation of $(1 R$, cis, $\alpha R S)$ - and (1R, trans, $\alpha R S)$-isomers of cypermethrin $[(R S)$ $\alpha$-cyano-3-phenoxybenzyl (1RS)-cis, trans-3-(2,2-dichlorovinyl)-2,2-dimethylcyclopropanecarboxylate] in water and on soil surface was studied, using ${ }^{14} \mathrm{C}$ preparations labeled separately at the cyclopropyl C-1, cyano or benzyl ring. The $c i s$-isomer was photodecomposed 1.4-1.7 times faster in sunlight than the trans-isomer in water. The half-life of the cis-isomer was 2.3-2.6 days in distilled water and $1 \mathrm{ppm}$ humic acid aqueous solution, and 0.6-0.7 day in natural river and sea water, and $<0.5$ day in $2 \%$ aqueous acetone. A triplet photosensitizer acetone together with the naturally occurring substances in river and sea water enhanced the photodegradation of both isomers. On three kinds of soil surface, both isomers were rapidly photodegraded with the initial half-life of 0.6-1.9 days. The photoreactions involved were: $1 R / 1 \mathrm{~S}$ and cis/trans isomerization of the cyclopropane ring, cleavage of the ester or diphenyl ether linkage, oxidation of the $\mathrm{CHO}$ group to the $\mathrm{COOH}$ group, hydration of the $\mathrm{CN}$ group to the $\mathrm{CONH}_{2}$ group, hydrolysis of the $\mathrm{CONH}_{2}$ group to the $\mathrm{COOH}$ group, oxidative cleavage of the halogenated side chain, dehalogenation, intramolecular cyclization to form $\gamma$ - or $\delta$-lactone, and photomineralization of the cyclopropyl $\mathrm{C}-1$, cyano and benzyl ring to ${ }^{14} \mathrm{CO}_{2}$.
\end{abstract}

\section{INTRODUCTION}

Cypermethrin [NRDC 149, (RS)- $\alpha$-cyano-3phenoxybenzyl (1RS)-cis, trans-3-(2,2-dichlorovinyl)-2,2-dimethylcyclopropanecarboxylate], $(P 1)$, is a mixture of eight isomers owing to three chiral centers at the cyclopropyl C-1 and $\mathrm{C}-3$, and the benzyl methine carbon atom. The insecticide has proved to be effective for the control of insect pests in cotton, top fruits and vegetable crops. ${ }^{1)}$ Cypermethrin is two to three times more active toward houseflies than permethrin, ${ }^{1-3)}$ and the (1RS)-cis-isomers are more active than the corresponding ( $1 R S)$ trans-isomers by a factor of two. ${ }^{4}$ From the viewpoint of environmental safety, studies on metabolism of $P 1$ in plants, ${ }^{5-7)}$ soils, ${ }^{8-11)}$ rats $^{12-14}$ and mice ${ }^{15,16)}$ have already been performed.
This paper deals with photodegradation of the $(1 R$, cis, $\alpha R S)$ - and $(1 R$, trans, $\alpha R S)$-isomers in water and soil surface in natural sunlight, using six kinds of ${ }^{14} \mathrm{C}$-labeled preparations.

\section{MATERIALS AND METHODS}

\section{Radioactive Chemicals}

The $(1 R, c i s, \alpha R S)$ - and (1R, trans, $\alpha R S)-P 1$ labeled with ${ }^{14} \mathrm{C}$ separately at the cyclopropyl $\mathrm{C}-1$ (referred to as cyclopropyl- ${ }^{14} \mathrm{C}$ ), cyano $\left({ }^{14} \mathrm{CN}\right)$ or benzyl ring (uniform labeling, benzyl${ }^{14} \mathrm{C}$ ) were synthesized at the Takarazuka Research Center, Sumitomo Chemical Co., Ltd. ${ }^{17}$ The specific activities were as follows: cyclopropyl $-{ }^{14} \mathrm{C}-P 1 ; 22.0 \mathrm{mCi} / \mathrm{mmol},{ }^{14} \mathrm{CN}-P 1 ; 28.0$ $\mathrm{mCi} / \mathrm{mmol}$, benzyl- ${ }^{14} \mathrm{C}-P 1 ; \quad 25.2 \mathrm{mCi} / \mathrm{mmol}$. Each preparation had more than $99 \%$ radiochemical purity as determined by thin-layer 
Table 1 Designation and chemical name of cypermethrin $(P I)$ and its derivatives.

\begin{tabular}{|c|c|}
\hline Designation & Chemical name \\
\hline$P 1$ & $\begin{array}{l}(R S) \text { - } \alpha \text {-Cyano-3-phenoxybenzyl }(1 R S) \text {-cis,trans-3-(2,2-dichlorovinyl)-2,2-dimethylcyclo- } \\
\text { propanecarboxylate }\end{array}$ \\
\hline$P 2$ & $\begin{array}{l}(R S) \text { - } \alpha \text {-Carbamoyl-3-phenoxybenzyl }(1 R) \text {-cis,trans-3-(2,2-dichlorovinyl)-2,2-dimethylcy- } \\
\text { clopropanecarboxylate }\end{array}$ \\
\hline$P 3$ & $\begin{array}{l}(R S) \text { - } \alpha \text {-Carboxy-3-phenoxybenzyl (1R)-cis,trans-3-(2,2-dichlorovinyl)-2,2-dimethylcyclo- } \\
\text { propanecarboxylate }\end{array}$ \\
\hline$P 4$ & $\begin{array}{l}(R S) \text { - } \alpha \text {-Cyano-3-hyroxybenzyl }(1 R) \text {-cis,trans-3-(2,2-dichlorovinyl)-2,2-dimethylcyclopro- } \\
\text { panecarboxylate }\end{array}$ \\
\hline P5 & $\begin{array}{l}(R S) \text { - } \alpha \text {-Carbamoyl-3-hyroxybenzyl }(1 R) \text {-cis-3-(2,2-dichlorovinyl)-2,2-dimethylcyclopro- } \\
\text { panecarboxylate }\end{array}$ \\
\hline$P 6$ & $(1 R)$-cis,trans-3-(2,2-dichlorovinyl)-2,2-dimethylcyclopropanecarboxylic acid \\
\hline$P 7$ & 3,3-Dimethylcyclopropane-1,2-dicarboxylic acid \\
\hline P8 & 3,3-Dimethylcyclopropane-1,2-dicarboxylic acid anhydride \\
\hline P9 & 6,6-Dichloro-3,3-dimethyl-4-hydroxy-5-hexenoic acid $\gamma$-lactone \\
\hline$P 10$ & 6-Chloro-3,3-dimethyl-4-hydroxy-5-hexenoic acid $\gamma$-lactone \\
\hline$P 11$ & 3-(2-Chloro-2-hydroxyvinyl)-2,2-dimethylcyclopropanecarboxylic acid $\delta$-lactone \\
\hline P12 & 3-Hydroxybenzoic acid \\
\hline$P 13$ & 3-Phenoxybenzaldehyde \\
\hline P14 & 3-Phenoxybenzoic acid \\
\hline$P 15$ & 3-(2-Hydroxyphenoxy)benzoic acid \\
\hline P16 & 3-(4-Hydroxyphenoxy)benzoic acid \\
\hline P17 & 3-Phenoxybenzyl cyanide \\
\hline$P 18$ & 3-Phenoxybenzylacetamide \\
\hline P19 & 3-Phenoxybenzylacetic acid \\
\hline$P 20$ & 1,2-Bis(3-phenoxyphenyl)-1,2-dicyanoethane \\
\hline$P 21$ & $\alpha$-Cyano-3-phenoxybenzyl alcohol \\
\hline$P 22$ & $\alpha$-Carbamoyl-3-phenoxybenzyl alcohol \\
\hline$P 23$ & $\alpha$-Carboxy-3-phenoxybenzyl alcohol \\
\hline
\end{tabular}

chromatography (TLC) on solvent systems A, $\mathrm{B}, \mathrm{C}$ and $\mathrm{D}$, followed by autoradiography and liquid scintillation counting (LSC).

\section{Unlabeled Chemicals}

Unlabeled chemicals, shown in Table 1, were synthesized for reference standards at the Takarazuka Research Center, Sumitomo Chemical Co., Ltd. ${ }^{5)} P 9, P 10$ and $P 11$ were prepared by irradiation of $c i s-P 6$ in $50 \%$ aqueous acetonitrile with UV light $(>300 \mathrm{~nm})$ from a $450 \mathrm{~W}$ high pressure mercury vapor lamp for $5 \mathrm{hr}$. The reaction mixture was fractionated on a column of silica gel with hexane/ethyl acetate $(3 / 1)$, and the photoproducts were purified by repetitive preparative TLC with several solvent systems. P9: NMR $\left(\mathrm{CDCl}_{3}\right)$ $\delta 5.94(1 \mathrm{H}, \mathrm{d}, J=9.5 \mathrm{~Hz}), 4.87$ (1 H, d, $J=9.5$ $\mathrm{Hz}), 2.40(2 \mathrm{H}, \mathrm{s}), 1.22(3 \mathrm{H}, \mathrm{s}), 1.07(3 \mathrm{H}, \mathrm{s})$ ppm; EI-MS $(m / z) 212(\mathrm{M}+4), 210(\mathrm{M}+2), 208$ (M), 173, 133, 131, 129, 125, 113, 56; IR (direct)
2950, 2910, 1780, 1620, 1460, 1280, 1220, 1190, 990, $914 \mathrm{~cm}^{-2}$. P10: NMR $\left(\mathrm{CDCl}_{3}\right) \delta 6.25(1 \mathrm{H}$, $\mathrm{dd}, J=1,7 \mathrm{~Hz}), \quad 5.79 \quad(1 \mathrm{H}, \mathrm{dd}, J=7,9 \mathrm{~Hz})$, $5.11(1 \mathrm{H}, \mathrm{dd}, J=1,9 \mathrm{~Hz}), 2.51(1 \mathrm{H}, \mathrm{d}, J=$ $17 \mathrm{~Hz}), 2.31(1 \mathrm{H}, \mathrm{d}, J=17 \mathrm{~Hz}), 1.23(3 \mathrm{H}, \mathrm{s})$, $1.05(3 \mathrm{H}, \mathrm{s})$ ppm; EI-MS $(m / z) 176(\mathrm{M}+2)$, $174(\mathrm{M}), 149,107,105,93,85,83,43$; IR (KBr) 2950, 2920, 1775, 1625, 1460, 1380, 1280, 1135, $990 \mathrm{~cm}^{-1}$. P11: NMR $\left(\mathrm{CDCl}_{3}\right) \delta 5.38(1 \mathrm{H}$, s), $2.62(1 \mathrm{H}, \mathrm{d}, J=4.3 \mathrm{~Hz}), 2.31(1 \mathrm{H}, \mathrm{d}$, $J=4.3 \mathrm{~Hz}), 1.21(3 \mathrm{H}, \mathrm{s}), 1.19(3 \mathrm{H}, \mathrm{s}) \mathrm{ppm}$; EI-MS $(m / z) 174(\mathrm{M}+2), 172(\mathrm{M}), 159,157$, 137, 129, 131, 109, 95, 93, 55, 53; IR (direct) $3090,2960,2920,1800,1680,1450,1185,1125$, $980,940,805 \mathrm{~cm}^{-1}$.

\section{Chromatography}

Precoated silica gel $60 \mathrm{~F}_{254}$ chromatoplates $(20 \times 20 \mathrm{~cm}$, a layer $0.25 \mathrm{~mm}$ thick, E. Merck) were used for analytical and preparative purposes. The solvent systems used, and the $R f$ 
Table 2 TLC $R f$ values of cypermethrin $(P l)$ and its degradation products.

\begin{tabular}{|c|c|c|c|c|}
\hline \multirow{2}{*}{ Chemical } & \multicolumn{4}{|c|}{$R f$ values } \\
\hline & $\mathrm{A}$ & $\mathrm{B}$ & $\mathrm{C}$ & $\mathrm{D}$ \\
\hline$(1 R S$, cis, $\alpha R S)-P 1$ & $0.43,0.48$ & 0.84 & 0.67 & 0.68 \\
\hline$(1 R S$, trans, $\alpha R S)-P 1$ & $0.36,0.40$ & 0.84 & 0.67 & 0.68 \\
\hline cis-P2 & 0.0 & $0.28, \quad 0.31$ & $0.25, \quad 0.28$ & $0.14,0.16$ \\
\hline trans-P2 & 0.0 & $0.27, \quad 0.29$ & $0.23, \quad 0.26$ & $0.13,0.15$ \\
\hline cis-P3 & 0.0 & $0.34, \quad 0.37$ & 0.57 & $0.17, \quad 0.20$ \\
\hline trans $-P 3$ & 0.0 & $0.33, \quad 0.34$ & 0.54 & $0.17, \quad 0.19$ \\
\hline$c i s-P 4$ & 0.0 & $0.31,0.34$ & 0.50 & $0.43, \quad 0.45$ \\
\hline trans-P4 & 0.0 & $0.30, \quad 0.32$ & 0.50 & $0.43, \quad 0.45$ \\
\hline$P 5$ & 0.0 & 0.05 & 0.16 & 0.04 \\
\hline cis-P6 & 0.02 & 0.26 & 0.57 & 0.45 \\
\hline trans-P6 & 0.01 & 0.26 & 0.57 & 0.38 \\
\hline$P 7$ & 0.0 & 0.26 & 0.20 & 0.15 \\
\hline$P 8$ & 0.02 & 0.48 & 0.42 & 0.39 \\
\hline$P 9$ & 0.09 & 0.47 & 0.44 & 0.44 \\
\hline P10 & 0.07 & 0.44 & 0.41 & 0.42 \\
\hline$P 11$ & 0.13 & 0.56 & 0.51 & 0.49 \\
\hline P12 & 0.0 & 0.15 & 0.31 & 0.18 \\
\hline$P 13$ & 0.43 & 0.45 & 0.69 & 0.61 \\
\hline P14 & 0.0 & 0.29 & 0.52 & 0.32 \\
\hline P15 & 0.0 & 0.28 & 0.34 & 0.17 \\
\hline P16 & 0.0 & 0.16 & 0.30 & 0.09 \\
\hline$P 17$ & 0.18 & 0.66 & 0.61 & 0.52 \\
\hline$P 18$ & 0.0 & 0.18 & 0.19 & 0.04 \\
\hline P19 & 0.0 & 0.42 & 0.46 & 0.19 \\
\hline P2O & 0.02 & 0.65 & 0.59 & 0.60 \\
\hline$P 21$ & 0.02 & 0.28 & 0.49 & 0.38 \\
\hline$P 22$ & 0.0 & 0.06 & 0.14 & 0.02 \\
\hline$P 23$ & 0.0 & 0.07 & 0.20 & 0.02 \\
\hline
\end{tabular}

A: hexane/diethyl ether (20/1), B: hexane/toluene/acetic acid (3/15/2), C: benzene saturated with formic acid/diethyl ether (10/3), D: toluene/diethyl ether/acetic acid (75/25/1).

values of $P 1$ and its degradation products are listed in Table 2. The resolved radioactive spots were detected by autoradiography and the non-radioactive compounds were visualized by UV fluorescence quenching or exposing to iodine vapor.

High-performance liquid chromatography (HPLC) was carried out by using a Shimadzu LC-4A instrument equipped with a Shimadzu SPD-2AS UV detector $(230 \mathrm{~nm})$, with a prepacked SUMIPAX-OA 2000 column cotaining a chiral adsorbent (Sumika Analytical Center Co., Ltd., $250 \mathrm{~mm} \times 4 \mathrm{~mm}$ i.d.), using hexane/ 1,2-dichloroethane/2-propanol (500/30/0.15) as a mobile phase $(1 \mathrm{ml} / \mathrm{min})$. The retention time of the eight isomers of $P 1$ is listed in Table 3 . The radioactive $P 1$ in acetone, which would
Table 3 Separation of the eight isomers of cypermethrin $(P 1)$ by HPLC.

\begin{tabular}{cc}
\hline Optical isomer & Retention time (min) \\
\hline$(1 R$, cis, $\alpha R)-P 1$ & 19.6 \\
$(1 R$, cis, $\alpha S)-P 1$ & 25.8 \\
$(1 S$, cis, $\alpha R)-P 1$ & 27.8 \\
$(1 S$, cis, $\alpha S)-P 1$ & 20.6 \\
$(1 R$, trans, $\alpha R)-P 1$ & 23.3 \\
$(1 R$, trans, $\alpha S)-P 1$ & 31.8 \\
$(1 S$, trans, $\alpha R)-P 1$ & 33.4 \\
$(1 S$, trans, $\alpha S)-P 1$ & 24.1
\end{tabular}

Column: SUMIPAX-OA 2000 (4 mm i.d. $\times$ $250 \mathrm{~mm}$ ), Mobile phase: hexane/1,2-dichloroethane/2-propanol (500/30/0.15), Flow rate: $1 \mathrm{ml} / \mathrm{min}$. 
contain the eight isomers, was obtained by scraping the corresponding gel region of developed TLC plates with solvent system A, eluted with acetone, and analyzed by HPLC. Quantitation of the eight isomers was carried out by directly collecting of the eluates into vials at 15 -sec intervals prior to LSC.

\section{Spectroscopy}

Infrared (IR) spectra were recorded on a Hitachi 285 IR Spectrometer. Nuclear magnetic resonance (NMR) spectra were obtained by a Hitachi R-40 (90 MHz) or JEOL-JNMFX-100 (100 MHz) spectrometer in deuteriochloroform containing $1 \%$ tetramethylsilane as an internal standard. Electron impact mass (EI-MS) spectra were recorded on a Hitachi M-80 Gas Chromatograph/Mass Spectrometer (GC-MS) equipped with a M-003 data system at $70 \mathrm{eV}$ using a direct insertion technique.

\section{Radioassay}

Liquid scintillation counting (LSC), combustion analysis and autoradiography were carried out according to the procedures reported previously. ${ }^{18)}$

\section{Photolysis Experiments \\ 6.1 Photolysis in water}

In addition to distilled water, $2 \%$ aqueous acetone and aqueous humic acid ( $1 \mathrm{ppm})$ solution as well as natural water from a river and the sea were utilized in the photolysis experiments. The aqueous humic acid solution was prepared as follows: $0.1 \mathrm{~N} \mathrm{NaOH}(1 \mathrm{ml})$ containing $5 \mathrm{mg}$ of humic acid (Aldrich Chemical Co., Ltd.) was added to distilled water $\left(\begin{array}{ll}5 & 1\end{array}\right)$ and stirred for $2 \mathrm{hr}$. The solution was adjusted to $\mathrm{pH} 6.3$ with $0.1 \mathrm{~N} \mathrm{HCl}$. Water was collected at the Muko River ( $\mathrm{pH}$ 8.7) or the seaside in Nishinomiya ( $\mathrm{pH}$ 8.3), Hyogo Prefecture, Japan. The water samples were sterilized through $0.1 \mu \mathrm{m}$ filter paper (No. $85 \mathrm{SB}, 60$ $\mathrm{mm}$ in diameter, Toyo Roshi Co., Ltd.) immediately before use.

Because of a rapid disappearance of $P 1$ in water even at below its water solubility (8.9 $\mathrm{ppb}$ at $25^{\circ} \mathrm{C}$ ), probably due to sticking to the glass wall, more stable suspensions of $P 1$ were prepared at $50 \mathrm{ppb}$, using Tween 85 (a surfactant, Wako Pure Chemical Co., Ltd.) which absorbs no UV above $290 \mathrm{~nm}$.

The ${ }^{14} \mathrm{C}-P 1$ suspension was prepared as follows: ${ }^{14} \mathrm{C}-P 1$ (400 g) and Tween $85(20 \mathrm{mg})$ were dissolved in chloroform $(10 \mathrm{ml})$ and $1 \mathrm{ml}$ of the solution was taken into a 1-liter quartz flask. After evaporating the solvent under reduced pressure, water $(800 \mathrm{ml})$ was added and then shaken for $1 \mathrm{hr}$ by a mechanical shaker to attain a level of $50 \mathrm{ppb}$. More than $95 \%$ of the radioactivity remained in the aqueous layer after standing for 10 days without stirring. Each flask was exposed to natural sunlight for 10 days (ca. $8 \mathrm{hr}$ per day in September in 1983). The sunlight intensity with wavelengths between 300 and $400 \mathrm{~nm}$ was approximately 290,1180 and $239 \mu \mathrm{W} / \mathrm{cm}^{2}$ at the beginning, middle and end of the day, respectively. While exposured to sunlight, each test tube covered with aluminum foil containing $10 \mathrm{~N} \mathrm{NaOH}$ solution $(10 \mathrm{ml})$ was kept in a 1 liter quartz flask in order to trap the volatile ${ }^{14} \mathrm{C}$ including ${ }^{14} \mathrm{CO}_{2}$ and $\mathrm{H}^{14} \mathrm{CN}$. No significant $\mathrm{pH}$ change was observed in the aqueous suspensions except $2 \%$ aqueous acetone, in which the $\mathrm{pH}$ decreased from 5.4 to 3.7 after 1-day exposure. A dark control experiment was also conducted by covering the flask with aluminum foil to ensure that a given product was derived through photochemical processes.

\subsection{Photolysis on soil surfaces}

The following soils were used in the experiments: Kodaira light clay (Tokyo Metropolis), Katano sandy loam (Hyogo Pref.) and Azuchi sandy clay loam (Shiga Pref.). The physicochemical characteristics are shown in Table 4. Soil thin-layer plates $(10 \times 10 \mathrm{~cm}, \quad 500 \mu \mathrm{m}$ thickness) were prepared with fine soil particles passed through a $2 \mathrm{~mm}$ sieve according to the method used by Helling et al. ${ }^{19)}$ Onto the soil TLC plate, ${ }^{14} \mathrm{C}-P 1$ in diethyl ether $(1 \mathrm{ml})$ was evenly applied with a brush at a rate of 1.1 $\mu \mathrm{g} / \mathrm{cm}^{2}$ and then exposed to natural sunlight during August 1983 in Takarazuka, Hyogo, Japan. Sunlight intensity with wavelengths between 300 and $400 \mathrm{~nm}$ was approximately 1010,1640 and $270 \mu \mathrm{W} / \mathrm{cm}^{2}$ at the beginning, middle and end of the day, respectively. During the photolysis, the water contents of Kodaira, Katano and Azuchi soil TLC plates changed from $12.1,1.4$ and $2.1 \%$ to $9.2,0.7$ and $1.5 \%$, respectively. A dark control ex- 
Table 4 Physico-chemical characteristics of soil used in the experiments.

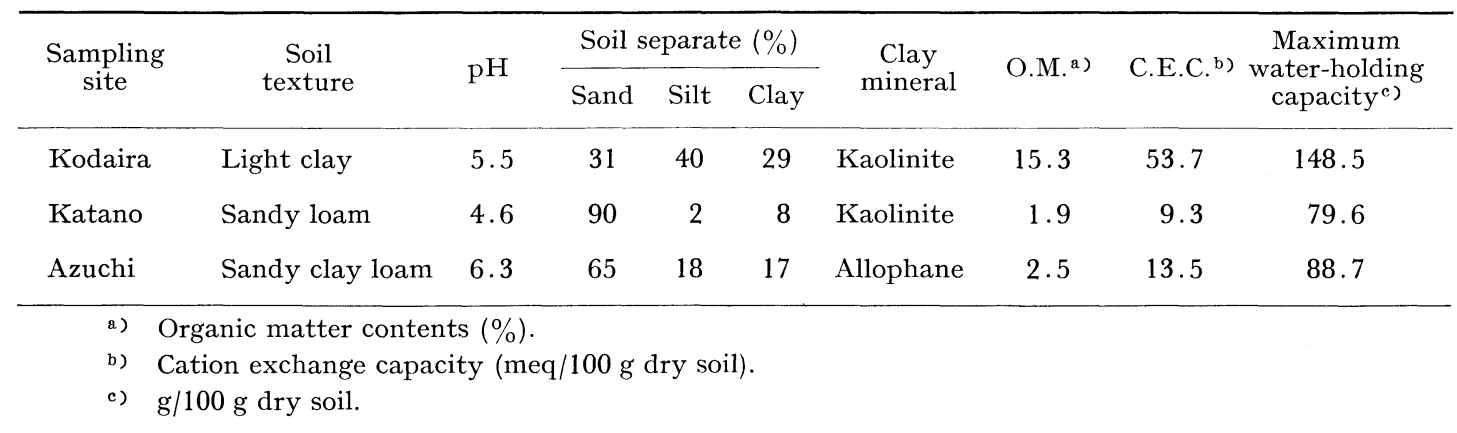

periment was conducted with by keeping the soil TLC plates in the dark.

\section{Extraction and Analysis}

\subsection{Aqueous suspensions}

At specified intervals after exposed to sunlight, $130 \mathrm{ml}$ of the suspension was taken into a gas-washing bottle and acidified to $\mathrm{pH} 1$ with $2 \mathrm{~N} \mathrm{H}_{2} \mathrm{SO}_{4}$ to determine the amount of ${ }^{14} \mathrm{CO}_{2}$ and/or $\mathrm{H}^{14} \mathrm{CN}$ prior to being subjected to extraction with a twofold volume of ethyl acetate. By bubbling of $\mathrm{N}_{2}$ gas into the acidified suspension at ca. $1500 \mathrm{ml} / \mathrm{min}$ for $30 \mathrm{~min}$, ${ }^{14} \mathrm{CO}_{2}$ and/or $\mathrm{H}^{14} \mathrm{CN}$ were introduced into a $0.6 \mathrm{~N} \mathrm{NaOH}$ solution $(200 \mathrm{ml})$. Recovery of each product exceeded $90 \%$. Following the precipitation of ${ }^{14} \mathrm{CO}_{2}$ in the alkaline solution as $\mathrm{Ba}^{14} \mathrm{CO}_{3}$ by adding $2 \mathrm{~N} \mathrm{BaCl}_{2}$, the solution was centrifuged at $5000 \mathrm{rpm}$ for $5 \mathrm{~min}$ to separate the supernatant from $\mathrm{Ba}^{14} \mathrm{CO}_{3}$. The supernatant was acidified to $\mathrm{pH} 3$ with $\mathrm{H}_{2} \mathrm{SO}_{4}$. Through the process $\mathrm{He}$ gas was bubbled at ca. $100 \mathrm{ml} / \mathrm{min}$ for $6 \mathrm{hr}$ to trap the liberated $\mathrm{H}^{14} \mathrm{CN}$ in a glass tube in liquid nitrogen. The $\mathrm{H}^{14} \mathrm{CN}$ trapped in a glass tube was dissolved in $0.1 \mathrm{~N} \mathrm{NaOH}(0.6 \mathrm{ml})$ and $0.5 \mathrm{ml}$ of the solution was subjected to the colorimetric analysis (560 nm) using $o$-dinitrobenzene and $p$-nitrobenzaldehyde. ${ }^{20}$ ) More than $80 \%$ of $\mathrm{HCN}$ with its amount ranging from $6 \mathrm{ng}$ to $150 \mathrm{ng}$ was recovered by the procedure described above. ${ }^{14} \mathrm{CO}_{2}$ and/or $\mathrm{H}^{14} \mathrm{CN}$ in the alkaline traps kept in a 1-liter quartz flask were analyzed by the same procedures.

The combined ethyl acetate extract from the aqueous suspension was radioassayed by LSC and the remainder was evaporated and analyzed by TLC and HPLC.

\subsection{Extraction of soil}

The soil thin-layer was scraped off and extracted with acetone/distilled water $(1 / 5,30$ $\mathrm{ml} \times 3$ ) by shaking for $10 \mathrm{~min}$. The mixture was centrifuged at $3000 \mathrm{rpm}$ for $5 \mathrm{~min}$ to separate the supernatant from the soil residue. The combined extract was assayed for ${ }^{14} \mathrm{C}$, evaporated and analyzed by TLC and HPLC. An aliquot of the unextractable soil residue was combusted prior to LSC and the remainder was fractionated into the fulvic acid, humic acid and humins according to the general procedures. $^{21)}$

\section{Determination of Quantum Yield}

The quantum yields of $(1 R, c i s)$ - and $(1 R$, trans)-P1, cis- and trans-P6, and $P 14$ were determined by comparing the photolysis rate with that of parathion as a reference compound at $313 \mathrm{~nm}$ using a merry-go-round type photochemical apparatus which was reported previously. ${ }^{18)}$ The aqueous solutions of radiolabeled $(1 R, c i s)$ - and (1R, trans)-P1 (50 ppb), cis- and trans-P6 (1 ppm), P14 (1 ppm) and parathion $(0.2 \mathrm{ppm})$ were placed into a quartz tube and irradiated for up to $24 \mathrm{hr}$.

\section{RESULTS}

\section{Photolysis in Water}

The photodegradation rates of $(1 R$, cis, $\alpha R S)$ and $(1 R$, trans, $\alpha R S)-P 1$ in water by natural sunlight decreased in the following order: $2 \%$ aqueous acetone $>$ river and sea water $>$ humic acid aqueous solution $=$ distilled water (Fig. 1). The cis-isomer was photodecomposed 1.4-1.7 times faster than the trans-isomer in solutions except $2 \%$ aqueous acetone, in which no significant difference was observed in the 
Table 5 Half-life values of $(1 R$, cis, $\alpha R S)$ - and $(1 R, \operatorname{trans} \alpha R S)$-cypermethrin $(P 1)$ in sunlight and darkness.

\begin{tabular}{|c|c|c|c|c|}
\hline & \multicolumn{4}{|c|}{ Half-life (days) } \\
\hline & \multicolumn{2}{|c|}{$(1 R, c i s, \alpha R S)-P 1$} & \multicolumn{2}{|c|}{$(1 R$, trans, $\alpha R S)-P 1$} \\
\hline & Sunlight & Dark & Sunlight & Dark \\
\hline \multicolumn{5}{|l|}{ Water } \\
\hline Distilled water & 2.6 & $\left.>10(95.6)^{a}\right)$ & 3.6 & $>10(94.4)^{a}$ \\
\hline Aqueous humic acid & 2.3 & $>10(95.8)^{\mathrm{a})}$ & 3.4 & $>10(95.2)^{a)}$ \\
\hline River water & 0.6 & $>10(88.7)^{\text {a })}$ & 1.0 & $>10(55.3)^{\mathrm{a})}$ \\
\hline Sea water & 0.7 & $\left.>10(83.9)^{a}\right)$ & 1.0 & $>10(59.6)^{\mathrm{a})}$ \\
\hline $2 \%$ Aqueous acetone & $<0.5$ & $>10(97.4)^{a)}$ & $<0.5$ & $\left.>10(95.0)^{a}\right)$ \\
\hline \multicolumn{5}{|l|}{ Soil } \\
\hline Kodaira & 0.6 & $>7(84.2)^{b)}$ & 0.7 & $>7(84.0)^{b)}$ \\
\hline Azuchi & 1.5 & $\left.>7(80.8)^{b}\right)$ & 1.3 & $>7(81.8)^{b)}$ \\
\hline Katano & 1.9 & $>7(94.2)^{\mathrm{b})}$ & 1.7 & $>7(91.4)^{b)}$ \\
\hline
\end{tabular}

a) Recovery (\%) of $P 1$ after 10 days in darkness.

b) Recovery (\%) of $P 1$ after 7 days in darkness.

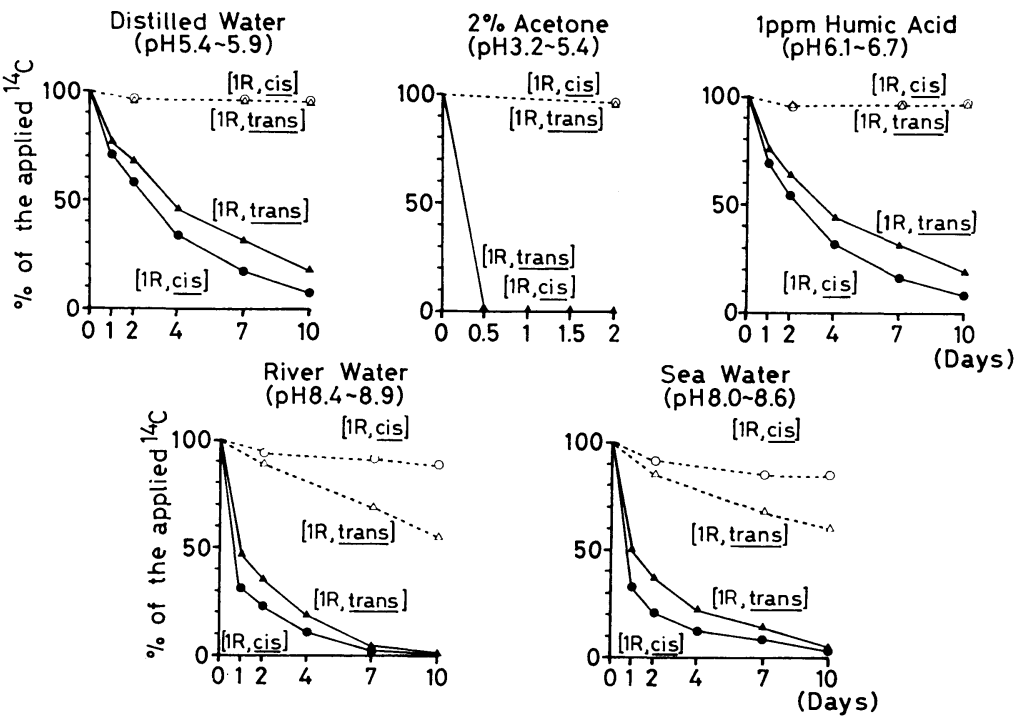

Fig. 1 Degradation of ${ }^{14} \mathrm{C}-(1 R, c i s, \alpha R S)$ - and $(1 R$, trans, $\alpha R S)$-cypermethrin $(P 1)$ in various kinds of aqueous suspensions in sunlight and darkness.

— : Sunlight, ….: Darkness.

photolysis rate. The half-life of disappearance ranged from $<0.5$ day to 3.6 days (Table 5). As estimated from the half-life values, the photodegradation of both isomers in river and sea water was $c a$. 3-4 times as rapid as that in distilled water, suggesting that a triplet photosensitizer acetone together with naturally occurring substances in river and sea water enhanced the photodegradation of both isomers. In darkness, both isomers were fairly stable in the solutions tested, but in slightly basic media such as river and sea water both isomers were gradually degraded. After 7 days, the recovered $P 1$ amounted to 53.3-59.6 and $83.9-88.7 \%$ of the applied ${ }^{14} \mathrm{C}$, respectively.

Both isomers underwent rapid and extensive 
Table 6 The amount of $(1 R, c i s, \alpha R S)$ - and $(1 R$, trans, $\alpha R S)$-cypermethrin $(P 1)$ and their photoproducts in distilled water and $2 \%$ aqueous acetone in sunlight.

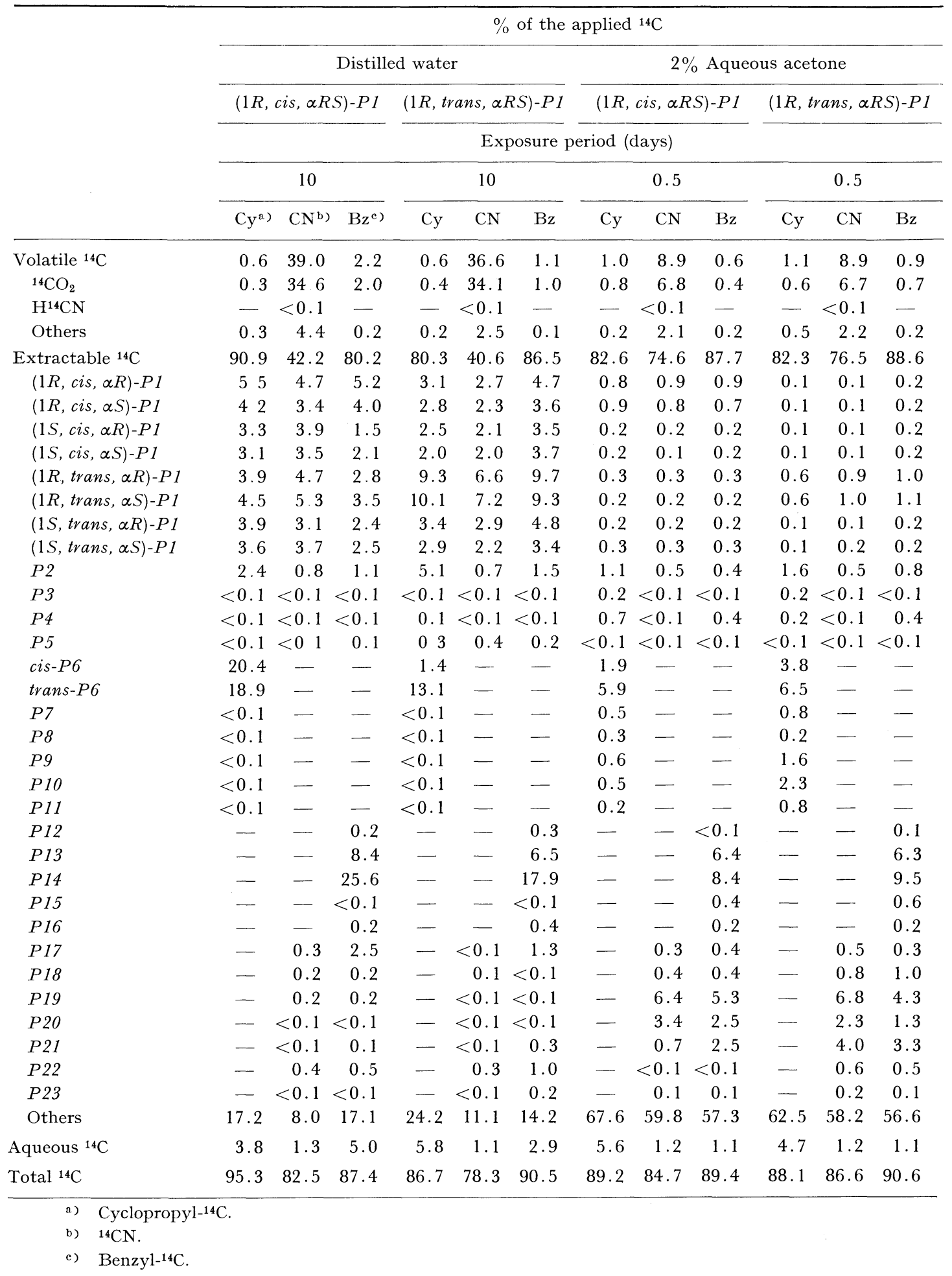


Table 7 The amount of $(1 R$, cis, $\alpha R S)$ - and $(1 R$, trans, $\alpha R S)$-cypermethrin $(P 1)$ and their photoproducts in river water and $1 \mathrm{ppm}$ humic acid aqueous solution in sunlight.

\begin{tabular}{|c|c|c|c|c|c|c|c|c|c|c|c|c|}
\hline \multirow{6}{*}{. } & \multicolumn{12}{|c|}{$\%$ of the applied ${ }^{14} \mathrm{C}$} \\
\hline & \multicolumn{6}{|c|}{ River water } & \multicolumn{6}{|c|}{ Humic acid aqueous solution } \\
\hline & \multicolumn{3}{|c|}{$(1 R, c i s, \alpha R S)-P 1$} & \multicolumn{3}{|c|}{$(1 R$, trans, $\alpha R S)-P 1$} & \multicolumn{3}{|c|}{$(1 R, c i s, \propto R S)-P 1$} & \multicolumn{3}{|c|}{$(1 R$, trans, $\alpha R S)-P I$} \\
\hline & \multicolumn{12}{|c|}{ Exposure period (days) } \\
\hline & \multicolumn{3}{|c|}{10} & \multicolumn{3}{|c|}{10} & \multicolumn{3}{|c|}{10} & \multicolumn{3}{|c|}{10} \\
\hline & $\left(y^{a}\right)$ & $\mathrm{CN}^{\mathrm{b})}$ & $\mathrm{Bz}{ }^{\mathrm{c})}$ & $\mathrm{Cy}$ & $\mathrm{CN}$ & $\mathrm{Bz}$ & $\mathrm{Cy}$ & $\mathrm{CN}$ & $\mathrm{Bz}$ & $\mathrm{Cy}$ & $\mathrm{CN}$ & $\mathrm{Bz}$ \\
\hline Volatile ${ }^{14} \mathrm{C}$ & 2.8 & 67.8 & 6.5 & 1.4 & 62.7 & 5.2 & 1.0 & 27.0 & 2.1 & 2.0 & 34.2 & 1.2 \\
\hline${ }^{14} \mathrm{CO}_{2}$ & 2.6 & 63.1 & 6.2 & 1.3 & 59.9 & 5.0 & 0.5 & 25.0 & 1.7 & 1.7 & 30.5 & 0.7 \\
\hline $\mathrm{H}^{14} \mathrm{CN}$ & - & $<0.1$ & - & - & $<0.1$ & - & - & $<0.1$ & - & - & $<0.1$ & - \\
\hline Others & 0.2 & 4.7 & 0.3 & 0.1 & 2.8 & 0.2 & 0.5 & 2.0 & 0.4 & 0.3 & 3.7 & 0.5 \\
\hline Extractable ${ }^{14} \mathrm{C}$ & 86.7 & 10.8 & 76.1 & 91.8 & 12.3 & 80.7 & 90.7 & 58.8 & 91.8 & 86.8 & 50.2 & 89.3 \\
\hline$(1 R$, cis, $\alpha R)-P 1$ & 0.1 & 0.5 & 0.1 & 0.2 & 0.3 & 0.1 & 2.6 & 6.2 & 5.2 & 3.5 & 3.4 & 3.9 \\
\hline$(1 R$, cis, $\alpha S)-P 1$ & 0.1 & 0.4 & 0.1 & 0.2 & 0.3 & $<0.1$ & 2.1 & 5.7 & 3.4 & 3.8 & 3.1 & 3.7 \\
\hline$(1 S$, cis, $\alpha R)-P 1$ & $<0.1$ & 0.2 & 0.2 & 0.2 & 0.4 & $<0.1$ & 1.8 & 5.1 & 3.9 & 3.2 & 3.6 & 3.2 \\
\hline$(1 S, c i s, \alpha S)-P 1$ & $<0.1$ & 0.2 & 0.2 & 0.2 & 0.4 & $<0.1$ & 2.0 & 5.8 & 4.1 & 4.1 & 3.2 & 3.9 \\
\hline$(1 R$, trans, $\alpha R)-P 1$ & 0.1 & 0.3 & 0.1 & 0.2 & 0.3 & 0.1 & 2.1 & 6.7 & 5.1 & 10.9 & 10.1 & 8.8 \\
\hline$(1 R$, trans, $\alpha S)-P 1$ & 0.2 & 0.2 & 0.2 & 0.3 & 0.3 & 0.1 & 2.5 & 7.1 & 4.7 & 10.0 & 9.7 & 8.5 \\
\hline$(1 S$, trans, $\alpha R)-P 1$ & $<0.1$ & 0.3 & 0.2 & 0.2 & 0.3 & 0.1 & 2.4 & 6.5 & 4.2 & 2.7 & 3.3 & 3.1 \\
\hline$(1 S$, trans, $\alpha S)-P 1$ & 0.1 & 0.2 & 0.1 & 0.2 & 0.3 & $<0.1$ & 2.2 & 6.9 & 5.2 & 3.9 & 2.9 & 3.4 \\
\hline$P 2$ & 0.8 & 0.4 & 0.5 & 0.6 & 0.7 & 0.2 & 0.2 & 0.3 & 1.0 & 2.5 & 0.7 & 0.7 \\
\hline$P 3$ & $<0.1$ & 0.2 & $<0.1$ & $<0.1$ & $<0.1$ & $<0.1$ & $<0.1$ & $<0.1$ & $<0.1$ & $<0.1$ & $<0.1$ & $<0.1$ \\
\hline$P 4$ & $<0.1$ & $<0.1$ & $<0.1$ & $<0.1$ & $<0.1$ & $<0.1$ & 0.1 & $<0.1$ & $<0.1$ & $<0.1$ & $<0.1$ & $<0.1$ \\
\hline$P 5$ & 0.1 & $<0.1$ & 0.6 & $<0.1$ & $<0.1$ & 0.1 & $<0.1$ & 0.1 & 0.2 & 0.2 & 0.2 & 0.1 \\
\hline cis-P6 & 30.7 & - & - & 24.1 & - & - & 26.1 & - & - & 2.3 & - & - \\
\hline trans $-P 6$ & 46.2 & - & - & 58.6 & - & - & 22.0 & - & - & 17.4 & - & - \\
\hline$P 7$ & $<0.1$ & - & - & $<0.1$ & - & - & $<0.1$ & - & - & $<0.1$ & - & - \\
\hline$P 8$ & $<0.1$ & - & - & $<0.1$ & - & - & $<0.1$ & - & - & $<0.1$ & - & - \\
\hline$P 9$ & $<0.1$ & - & - & $<0.1$ & - & - & $<0.1$ & - & - & $<0.1$ & - & - \\
\hline$P 10$ & $<0.1$ & - & - & $<0.1$ & - & - & $<0.1$ & - & - & $<0.1$ & - & - \\
\hline$P 11$ & $<0.1$ & - & - & $<0.1$ & - & - & $<0.1$ & - & - & $<0.1$ & - & - \\
\hline$P 12$ & - & - & 0.2 & - & - & 0.2 & - & - & 0.3 & - & - & 0.3 \\
\hline$P 13$ & - & - & 0.2 & - & - & 0.1 & - & - & 6.4 & - & - & 4.7 \\
\hline P14 & - & - & 59.2 & - & - & 67.8 & - & - & 29.8 & - & - & 29.3 \\
\hline$P 15$ & - & - & 1.9 & - & - & 1.1 & - & - & 0.3 & - & - & 0.2 \\
\hline P16 & - & - & 0.6 & - & - & 0.4 & - & - & 0.4 & - & - & 0.3 \\
\hline P17 & - & 0.4 & $<0.1$ & - & 0.4 & 0.2 & - & 0.4 & 1.5 & - & 0.5 & 1.0 \\
\hline$P 18$ & - & 0.1 & 0.1 & - & 0.1 & $<0.1$ & - & 0.1 & 0.1 & - & 0.1 & 0.1 \\
\hline$P 19$ & - & 0.2 & 0.2 & - & 0.1 & 0.1 & - & $<0.1$ & 0.2 & - & $<0.1$ & $<0.1$ \\
\hline$P 20$ & - & $<0.1$ & $<0.1$ & - & $<0.1$ & $<0.1$ & - & $<0.1$ & $<0.1$ & - & $<0.1$ & $<0.1$ \\
\hline$P 21$ & - & 0.2 & $<0.1$ & - & $<0.1$ & 0.2 & - & 0.6 & 0.8 & - & 0.5 & 0.6 \\
\hline$P 22$ & - & 1.7 & 2.3 & - & 3.1 & 2.4 & - & 0.2 & 0.7 & - & 0.3 & 0.4 \\
\hline$P 23$ & - & 0.3 & 0.2 & - & 0.2 & 0.2 & - & 0.1 & 0.2 & - & 0.1 & 0.1 \\
\hline Others & 8.3 & 5.0 & 9.0 & 6.9 & 5.2 & 7.3 & 24.7 & 7.4 & 14.4 & 22.3 & 8.5 & 13.1 \\
\hline Aqueous ${ }^{14} \mathrm{C}$ & 5.2 & 4.8 & 7.4 & 2.6 & 4.7 & 7.2 & 5.6 & 0.9 & 3.9 & 3.7 & 0.9 & 2.9 \\
\hline Total ${ }^{14} \mathrm{C}$ & 94.7 & 83.4 & 90.0 & 95.8 & 79.7 & 93.1 & 97.3 & 86.7 & 97.8 & 92.5 & 85.3 & 93.5 \\
\hline
\end{tabular}

a) Cyclopropyl-14 $\mathrm{C}$.

b) ${ }^{14} \mathrm{CN}$.

c) Benzyl- ${ }^{14} \mathrm{C}$ 


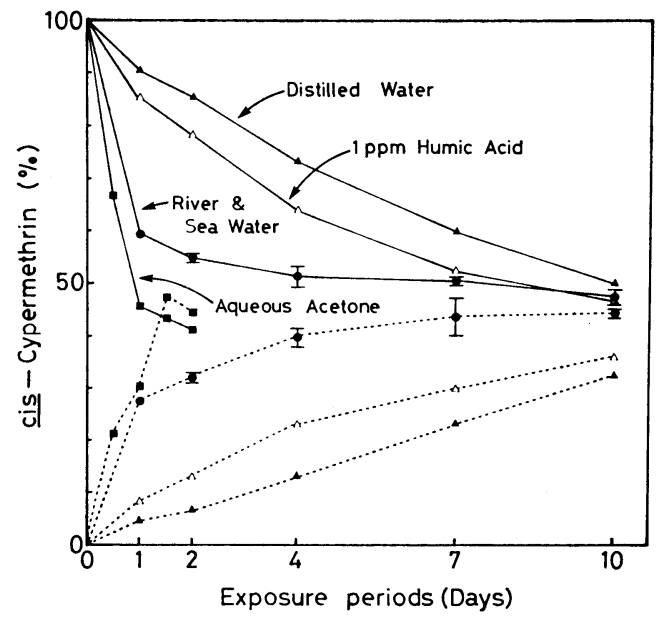

Fig. 2 Relative isomerization rates leading to equilibrium cis/trans mixtures of (1R, cis, $\alpha R S)$ or $(1 R$, trans, $\alpha R S)$-cypermethrin $(P 1)$ in water.

$-:(1 R$, cis, $\alpha R S)-P 1,---:(1 R$, trans, $\alpha R S)-$

$P 1$. $\Delta$, Distilled water; $\triangle, 1 \mathrm{ppm}$ humic acid;

๑, River and sea water; $\boldsymbol{\square}, 2 \%$ Aqueous acetone.

isomerization of the cyclopropane ring, i.e. interconversion of the trans- and cis-isomers, the reaction occurring most rapidly in the presence of acetone and declining, in order, in river and sea water, humic acid aqueous solution and distilled water (Fig. 2). This indicated that acetone, together with naturally occurring substances in river and sea water such as humic acids, enhanced the photoisomerization of both isomers. The cis-isomer underwent isomerization more rapidly than the transisomer in any water tested. Isomerization of the cyclopropane ring reached an equilibrium within 10 days except in distilled water and humic acid aqueous solution. At equilibrium, the more thermodynamically stable transisomer constituted $51-59 \%$ of the isomer mixture.

Tables 6 and 7 show the amount of the cisand trans-isomers and their photodegradation products in water. The cis/trans and $1 R / 1 S$ isomerization products and ester cleavage products $(P 6, P 14)$ were common major photoproducts, with a relatively large amount of $P 13$ in distilled water and P13 and P19 in 2\% aqueous acetone. The evolution of ${ }^{14} \mathrm{CO}_{2}$ from the ${ }^{14} \mathrm{CN}$ label was more significant than that from the cyclopropyl- and benzyl- ${ }^{14} \mathrm{C}$ labels

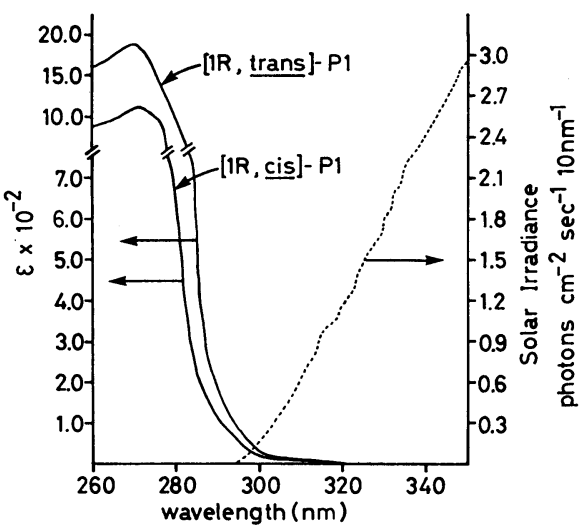

Fig. 3 Comparison of UV spectra of (1R, cis, $\alpha R S)$ - and (1R, trans, $\alpha R S)$-cypermethrin $(P 1)$ with solar irradiance.

in any water tested. However, $\mathrm{H}^{14} \mathrm{CN}$ remained below the detection limit $(0.1 \%$ of the applied ${ }^{14} \mathrm{C}$ ). The distribution of the photoproducts in sea water was almost the same as that in river water. The ester cleavage and isomerization of the cyclopropane ring were slightly enhanced in humic acid aqueous solution but not in distilled water. Both $P 6$ and P14 were of more importance than the isomerization products in river water, humic acid aqueous solution and $2 \%$ aqueous acetone, although they were formed as much as the isomerization products in distilled water. These evidences indicated that the ester bond cleavage following subsequent photomineralization of the $\mathrm{CN}$ fragment to $\mathrm{CO}_{2}$ was accelerated by acetone and natural substances in river and sea water which contained humic acids. The photoproducts unique in $2 \%$ aqueous acetone were $P 7, P 8, P 9, P 10$ and $P 11$ which amounted to $0.2-2.3 \%$ of the applied ${ }^{14} \mathrm{C}$ after one day, showing no tendency to increase with time. The other products such as P2, P3, P4, P5, P12, P15, P16, P17, P18, $P 20, P 21, P 22$ and $P 23$ were of minor importance in any water tested.

\section{Direct Photolysis Rate}

The direct photolysis half-lives of the $(1 R$, cis)- and ( $1 R$, trans)-P1 and other major photoproducts such as cis- and trans-P6 and P14 in distilled water near the surface were calculated according to the equation of $T_{1 / 2}=0.693 /\left(\phi k_{\mathrm{a}}\right)$ 
Table 8 Half-life of disappearance of $(1 R, c i s$, $\alpha R S)$ - and (1R, trans, $\alpha R S)$-cypermethrin (P1) and their major photoproducts in distilled water in natural sunlight in fall at $40^{\circ}$ North Latitude.

\begin{tabular}{|c|c|c|c|}
\hline \multirow{2}{*}{ Compound } & \multirow{2}{*}{$\phi^{\text {a })}$} & \multicolumn{2}{|c|}{ Half-life (days) } \\
\hline & & Calcd. ${ }^{\text {b) }}$ & Found \\
\hline$(1 R$, cis,$\alpha R S)-P 1$ & 0.16 & 2.8 & 2.6 \\
\hline$(1 R$, trans, $\alpha R S)-P 1$ & 0.097 & 3.7 & 3.6 \\
\hline cis-P6 & 0.035 & 22.3 & - \\
\hline trans-P6 & 0.017 & 32.9 & - \\
\hline$P 14$ & 0.00047 & 183.0 & - \\
\hline
\end{tabular}

a) Disappearance quantum yield.

b) Calculated half-life according to the equation of $T_{1 / 2}=0.693 /\left(\phi k_{\mathrm{a}}\right)$.

in fall at $40^{\circ} \mathrm{N}$ (Table 8 ). The quantum yield $(\phi$; three replicate measurements in distilled water at $313 \mathrm{~nm}$ ) and the rate of specific sunlight absorption $\left(k_{\mathrm{a}}\right)$ were determined according to the method reported previously (Fig. 3). ${ }^{18)}$ The quantum yield of the cis-isomers of both $P 1$ and $P 6$ were 1.6-2.1 times higher than that of the trans-isomers. The calculated halflife of $P 1$ was in good accord with that observed in the outdoor experiments. Estimates based on the calculated half-lives, seem to show that $P 6$ and P14 gradually undergo further photodegradation in water by natural sunlight.

\section{Photolysis on Soil Surfaces}

As shown in Fig. 4 and Table 5, sunlight had a significant effect on the degradation of $(1 R, c i s)-$ and $(1 R$, trans $)-P 1$ on three types of soils used for the experiments. The halflives of disappearance of both isomers were $0.6-0.7,1.3-1.5$ and $1.7-1.9$ days on the Kodaira, Azuchi and Katano soils, respectively. No significant difference was observed in two isomers' degradation rate.

After 7 days more than $60 \%$ of the applied ${ }^{14} \mathrm{C}$ was recovered from the soil and the remaining ${ }^{14} \mathrm{C}$ was lost probably due to evaporation (Table 9). More of the radiocarbon was lost from the Azuchi and Katano soils treated with the cyclopropyl- ${ }^{14} \mathrm{C}$ and ${ }^{14} \mathrm{CN}$ labels than those treated with the benzyl- ${ }^{14} \mathrm{C}$ label. By contrast, there was no significant loss of radioactivity in the dark.

Major degradation products were $P 2$ in the Kodaira soil and $P 2$ and $P 14$ in the Azuchi and Katano soils. The amide analog $(P 2)$ gradually increased with time. Although $P 2$ was also formed in darkness, sunlight significantly accelerated the transformation of $P 1$ to $P 2$ on soil surfaces. As compared with the photolysis in water, the cis/trans or $1 R / 1 S$ isomerization products were of minor importance, which amounted to less than $3 \%$ of the applied ${ }^{14} \mathrm{C}$ after 7 days in any soil tested. The other products such as $P 2, P 3, P 4, P 5, P 12, P 13$,
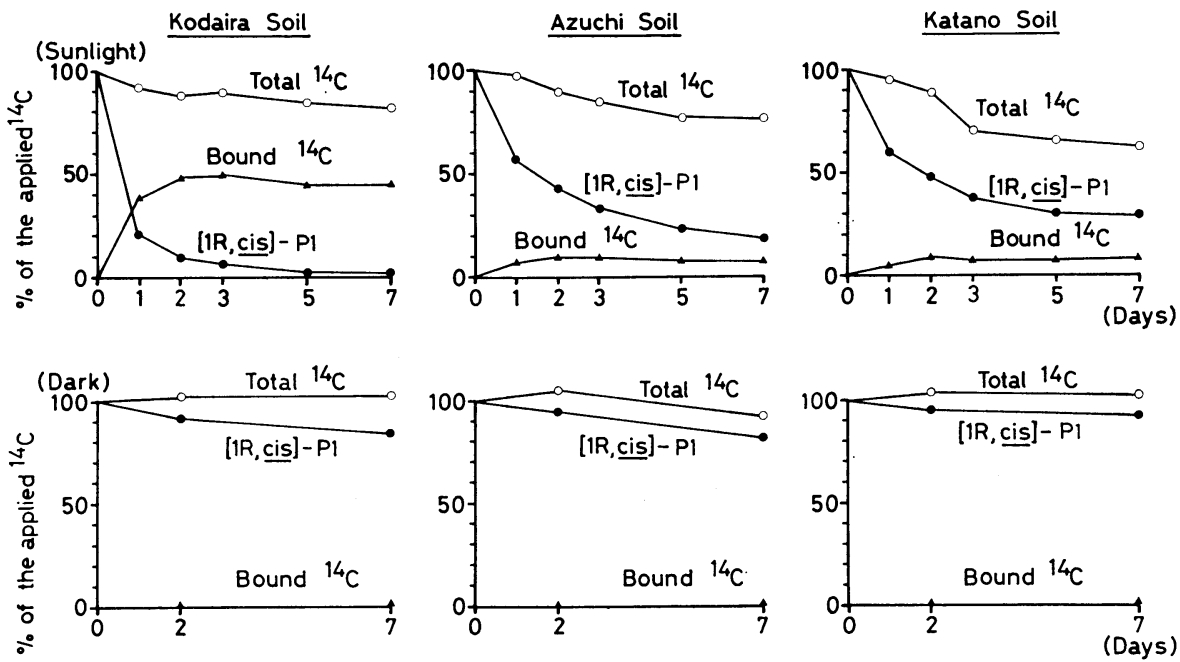

Fig. 4 Degradation of ${ }^{14} \mathrm{CN}-(1 R$, cis, $\alpha R S)$-cypermethrin $(P I)$ on soil surfaces in sunlight and darkness. 
Table 9 The amount of $(1 R, c i s, \alpha R S)$-cypermethrin $(P 1)$ and their photodegradation products in three kinds of soils in sunlight or darkness after 7 days.

\begin{tabular}{|c|c|c|c|c|c|c|c|c|c|c|c|c|}
\hline & \multicolumn{12}{|c|}{$\%$ of the applied ${ }^{14} \mathrm{C}$} \\
\hline & \multicolumn{4}{|c|}{ Kodaira } & \multicolumn{4}{|c|}{ Azuchi } & \multicolumn{4}{|c|}{ Katano } \\
\hline & \multicolumn{3}{|c|}{ Sunlight } & \multirow{2}{*}{$\frac{\text { Dark }}{\mathrm{Bz}}$} & \multicolumn{3}{|c|}{ Sunlight } & \multirow{2}{*}{$\frac{\text { Dark }}{\mathrm{Bz}}$} & \multicolumn{3}{|c|}{ Sunlight } & \multirow{2}{*}{$\frac{\text { Dark }}{\mathrm{Bz}}$} \\
\hline & $\left(y^{a}\right)$ & $\left.\mathrm{CN}^{\mathrm{b}}\right)$ & $\left.B z^{c}\right)$ & & $\mathrm{Cy}$ & $\mathrm{CN}$ & $\mathrm{Bz}$ & & $\mathrm{Cy}$ & $\mathrm{CN}$ & $\mathrm{Bz}$ & \\
\hline Extract ${ }^{14} \mathrm{C}$ & 37.3 & 35.9 & 40.2 & 101.2 & 65.6 & 68.9 & 76.0 & 87.7 & 57.7 & 54.0 & 70.1 & 97.1 \\
\hline$(1 R$, cis, $\alpha R)-P 1$ & 1.0 & 4.9 & 5.3 & 72.4 & 31.2 & 27.7 & 29.2 & 84.7 & 35.2 & 30.2 & 33.4 & 95.9 \\
\hline$(1 R$, cis, $\alpha S)-P 1$ & 1.1 & 0.9 & 1.1 & 44.0 & 10.2 & 10.6 & 9.0 & 37.8 & 16.2 & 15.7 & 12.5 & 45.7 \\
\hline$(1 S$, cis, $\alpha R)-P 1$ & 0.1 & 0.1 & $<0.1$ & 0.1 & 0.3 & 0.3 & 0.2 & 0.3 & 0.6 & 0.5 & 0.5 & 0.4 \\
\hline$(1 S, c i s, \alpha S)-P 1$ & 0.1 & 0.1 & $<0.1$ & 0.1 & 0.2 & 0.3 & 0.3 & 0.1 & 0.3 & 0.3 & 0.3 & 0.3 \\
\hline$(1 R$, trans, $\alpha R)-P 1$ & 0.1 & 0.1 & 0.1 & 0.1 & 0.3 & 0.2 & 0.2 & 0.2 & 0.4 & 0.5 & 0.4 & 0.3 \\
\hline$(1 R$, trans, $\alpha S)-P 1$ & 0.1 & $<0.1$ & $<0.1$ & 0.2 & 0.2 & 0.2 & 0.2 & 0.3 & 0.4 & 0.4 & 0.4 & 0.2 \\
\hline$(1 S$, trans, $\alpha S)-P 1$ & $<0.1$ & $<0.1$ & $<0.1$ & 0.1 & 0.1 & 0.3 & 0.2 & 0.3 & 0.5 & 0.4 & 0.4 & 0.3 \\
\hline$(1 S$, trans, $\alpha S)-P 1$ & 0.1 & 0.1 & $<0.1$ & 0.2 & 0.2 & 0.2 & 0.3 & 0.2 & 0.4 & 0.4 & 0.6 & 0.2 \\
\hline$P 2$ & 25.1 & 24.0 & 23.4 & 9.5 & 31.2 & 32.6 & 31.7 & 5.8 & 4.8 & 5.3 & 4.4 & 1.1 \\
\hline P3 & 1.0 & 1.0 & 0.9 & 0.1 & $<0.1$ & $<0.1$ & $<0.1$ & 0.4 & 0.1 & 0.1 & $<0.1$ & $<0.1$ \\
\hline$P 4$ & $<0.1$ & $<0.1$ & $<0.1$ & $<0.1$ & 0.1 & $<0.1$ & $<0.1$ & $<0.1$ & $<0.1$ & 0.3 & 0.9 & $<0.1$ \\
\hline$P 5$ & 0.2 & 0.4 & 0.5 & $<0.1$ & 0.4 & 0.3 & 0.6 & $<0.1$ & 0.4 & 0.2 & 0.2 & $<0.1$ \\
\hline$P 6$ & $<0.1$ & - & - & - & $<0.1$ & - & - & - & $<0.1$ & - & - & 一 \\
\hline P12 & - & - & 0.2 & $<0.1$ & - & - & 0.8 & $<0.1$ & - & - & 1.8 & $<0.1$ \\
\hline$P 13$ & - & - & $<0.1$ & $<0.1$ & - & - & 0.1 & $<0.1$ & - & - & 0.2 & $<0.1$ \\
\hline$P 14$ & - & - & 2.6 & 0.4 & - & - & 6.8 & 0.3 & - & - & 11.7 & 0.4 \\
\hline P16 & - & - & $<0.1$ & $<0.1$ & - & - & 0.1 & 0.4 & - & - & 0.4 & $<0.1$ \\
\hline$P 17$ & - & $<0.1$ & $<0.1$ & $<0.1$ & - & $<0.1$ & 0.2 & 0.2 & - & 0.5 & 0.5 & 0.2 \\
\hline P18 & - & $<0.1$ & $<0.1$ & $<0.1$ & - & $<0.1$ & $<0.1$ & $<0.1$ & - & $<0.1$ & $<0.1$ & $<0.1$ \\
\hline$P 21$ & - & $<0.1$ & $<0.1$ & 0.3 & - & 0.1 & 0.3 & 0.2 & - & 0.8 & 1.1 & 0.3 \\
\hline$P 22$ & - & 2.5 & 3.0 & $<0.1$ & - & 1.9 & 2.1 & $<0.1$ & - & 0.7 & 0.6 & $<0.1$ \\
\hline$P 23$ & - & 0.3 & 0.2 & $<0.1$ & - & 0.1 & 0.1 & $<0.1$ & - & $<0.1$ & 0.1 & $<0.1$ \\
\hline Others & 8.4 & 5.5 & 7.2 & 1.0 & 14.2 & 11.5 & 14.0 & 2.0 & 20.1 & 12.8 & 20.4 & 1.9 \\
\hline Bound ${ }^{14} \mathrm{C}$ & 47.3 & 45.6 & 45.4 & 2.1 & 11.3 & 7.9 & 9.8 & 0.5 & 11.6 & 7.6 & 12.9 & 0.4 \\
\hline Humic acid & 5.0 & 7.9 & 8.0 & $*$ d) & 1.4 & 1.1 & 1.7 & $*$ & 2.1 & 1.5 & 3.4 & $*$ \\
\hline Humin & 19.3 & 26.7 & 26.1 & $*$ & 1.8 & 1.4 & 2.7 & $*$ & 1.4 & 0.8 & 2.8 & $*$ \\
\hline Fulvic acid & 23.0 & 11.0 & 11.3 & $*$ & 8.1 & 5.4 & 5.4 & $*$ & 8.1 & 5.3 & 6.7 & $*$ \\
\hline Total ${ }^{14} \mathrm{C}$ & 84.6 & 81.5 & 85.6 & 103.3 & 76.9 & 76.8 & 85.8 & 88.2 & 69.3 & 61.6 & 83.0 & 97.5 \\
\hline $\begin{array}{l}\text { a) Cyclopropy } \\
\text { b) }{ }^{14} \mathrm{CN} \text {. } \\
\text { c) Benzyl-14 } \mathrm{C} \text {. Not detern }\end{array}$ & & & & & & & & & & & & \\
\hline
\end{tabular}

P16, P17, P18, P19, P21, P22 and P23 were also of minor importance.

\section{DISCUSSION}

$(1 R$, cis, $\alpha R S)$ - and $(1 R$, trans, $\alpha R S)$-cypermethrin $(P 1)$ have their absorption maxima significantly below $290 \mathrm{~nm}$ but have measurable absorption tails above the base line in their absorption spectra at wavelengths greater than $290 \mathrm{~nm}$. The UV spectra of the cis- and trans-isomers in acetonitrile/water $(1 / 1)$ exhibit $198-\mathrm{nm}(\epsilon 29,200)$ and $196-\mathrm{nm}(\epsilon 41,200)$ bands, respectively, for the allowed $\pi-\pi^{*}$ transition of the phenyl rings and 273-nm ( $\epsilon$ 1100) and 272-nm $(\epsilon 1900)$ bands, respectively, which are essentially $n-\pi^{*}$ in character, resulting from the combined transitions of the carbonyl group and the lower energy band of the aromatic rings. These $\pi-\pi^{*}$ and $n-\pi^{*}$ transitions can lead to the production of either singlet or 
triplet excited state, so no unique excited state can be invoked to explain the variety of photochemical reactions. The energy levels of singlet and triplet excited states of the cis-isomer were determined to be 89.3 and $59.6 \mathrm{kcal} /$ mole, respectively, by measuring the fluorescence and phosphorescence spectra in acetonitrile. $^{22)}$

The half-lives of disappearance of the cisand trans-isomers in water and on soil surface in natural sunlight or darkness are summarized in Table 5. Natural substances in river and sea water appear to accelerate the photodegradation of both isomers. It has been reported that humic acids, tryptophan and tyrosine in natural water act as photosensitizers towards some kind of pesticides in the environment. ${ }^{23-25)}$ At least humic acids accelerated the cis/trans isomerization of both isomers of cypermethrin in water. In the dark the transisomer was degraded more rapidly than the cis-isomer in slightly basic media. The hydrolysis study revealed that the trans-isomer was hydrolyzed 1.2-1.7 times more rapidly than the cis-isomer between $\mathrm{pH} 3$ and $\mathrm{pH}$ 12. ${ }^{26)}$ Although photodegradation of both isomers was also significant on soil surfaces, no distinct difference in the photolysis rate was observed, which was not the case with the photolysis in water. The photodegradation rate on soil surface was closely correlated with the contents of organic matter in soil, with the correlation coefficients being 0.94 to 0.97 .

The comparative photolysis study of synthetic pyrethroids in distilled water has shown that the photodegradation rate decreased in the order of deltamethrin > cypermethrin $>$ permethrin $>$ fenvalerate, with the half-lives of 1.4 to 10 days. ${ }^{27)}$ The photostability of cypermethrin, compared with that of deltamethrin, is attributed to the lower quantum yield and the lower rate of specific sunlight absorption. ${ }^{27)}$

Based upon the identified products, the proposed photodegradation pathways of $P 1$ are shown in Fig. 5. The cis- and trans-P1 were decomposed via pathways including $1 R / 1 S$ and cis/trans isomerization of the cyclopropane ring, cleaving of the ester or diphenyl ether linkage, oxidation of the $\mathrm{CHO}$ group to the $\mathrm{COOH}$ group, hydration of the $\mathrm{CN}$ group to the $\mathrm{CONH}_{2}$ group, hydrolysis of the $\mathrm{CONH}_{2}$ group to the $\mathrm{COOH}$ group, oxidative cleaving of the halogenated side chain, dehalogenation, and intramolecular cyclization to form $\gamma$ - or $\delta$-lactone. The product distribution depended upon a phase in which the reaction developed. The identified photoproducts in water were produced predominantly through $1 R / 1 S$ or cis/trans isomerization and/or ester-cleaving reactions. At equilibrium, although the more thermodynamically stable trans-isomer was more predominant than the cis-isomer, the ratio of $1 R / 1 S$ of isomerized photoproducts was close to unity. It seems that cis/trans or $1 R /$ $1 S$ isomerization occurs through re-combination of the biradical which was formed via cleavage of the $\mathrm{C}-1-\mathrm{C}-3$ bond. ${ }^{28)}$ The isomerization appears to proceed in part via a triplet excited state, since the reaction was considerably enhanced in the presence of acetone $\left(E_{\mathrm{t}}=\right.$ $78 \mathrm{kcal} / \mathrm{mol})$ and benzophenone $\left(E_{\mathrm{t}}=69 \mathrm{kcal} /\right.$ $\mathrm{mol})$, and efficiently quenched by 1,3-cyclohexadiene $\left(E_{\mathrm{t}}=50 \mathrm{kcal} / \mathrm{mol}\right)$ and molecular oxygen $^{22)}$ and so does the photolysis of deltamethrin. ${ }^{28)}$ In the photolysis of deltamethrin, the $\alpha R / \alpha S$ epimerization has also been observed. In the present study the $\alpha R / \alpha S$ epimerization was not persued because of the usage of a racemic mixture at the benzylic carbon atom. The photo-induced isomerization products were further degraded to $P 6$ and $P 14$ by the scission of the acyl-oxygen bond. There existed more ester cleavage products in natural river and sea water than in distilled water. $\mathrm{H}^{14} \mathrm{CN}$ released on scission of the acyl-oxygen bond was promptly transformed at least in part to ${ }^{14} \mathrm{CO}_{2}$ by natural sunlight and hardly detected in water.

The photoproducts unique in $2 \%$ aqueous acetone were $P 7, P 8, P 9, P 10, P 11$ and $P 20$. It appears that the former two photoproducts arise from oxidation of the halogenated side chain. $P 9$ and $P 10$ are formed via $\mathrm{C}-1-\mathrm{C}-3$ bond cleavage of the cyclopropane ring with subsequent rearrangement to the enol radical followed by intramolecular re-combination. These photochemical reactions were also observed in the photolysis of other pyrethroids such as pyrethrin I, allethrin, phthalthrin, dimethrin ${ }^{29}$ and vaporthrin. ${ }^{30)}$ P11 is formed by intramolecular cyclization of the dechlorinated 


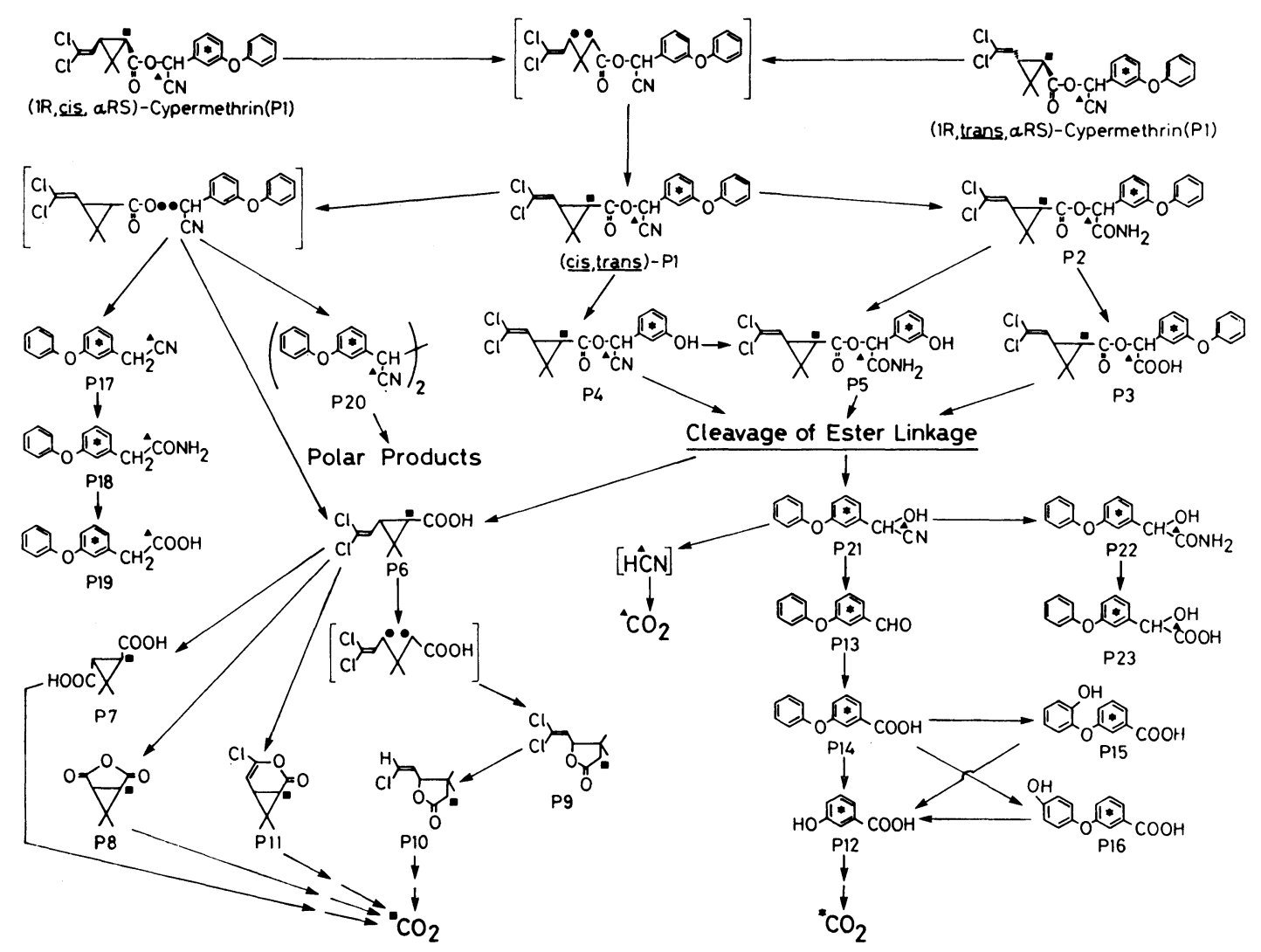

Fig. 5 Proposed photodegradation pathways of cypermethrin $(P 1)$.

D. Cyclopropyl-14 $\mathrm{C} ; \boldsymbol{\Delta},{ }^{14} \mathrm{CN} ; \star$, Benzyl-14 $\mathrm{C}$.

radical with the carboxyl group. $P 20$ is formed via self-coupling of the $\alpha$-cyano-3phenoxybenzyl radicals which were derived by cleavages of the ester oxygen-benzyl carbon bond. ${ }^{31)}$

On soil surfaces the cis/trans or $1 R / 1 S$ isomerization hardly occurred, and neither did the photolysis of permethrin. ${ }^{32)}$ Probably, other reactions proceeded in preference to the isomerization in the solid phase. ${ }^{33)}$

In contrast to the reductive dehalogenation of deltamethrin, ${ }^{28)}$ the photo-induced dechlorination of cypermethrin and permethrin ${ }^{32)}$ was quite limited. The chlorine-carbon bond of these pyrethroids appears to be relatively rigid, compared with the bromine-carbon bond.

The identified major photoproducts in water and on soil were also detected among the metabolites of $P 1$ in plants, ${ }^{5-7)}$ soils, $^{8-11)}$ rats $^{12-14)}$ and mice. ${ }^{15,16)}$ Major photoproducts such as $P 6$ and $P 14$ were biodegradable in nature and less toxic than $P 1$ to killifish with $48 \mathrm{hr} \mathrm{LC}_{50}$ values of more than $10 \mathrm{ppm}^{34)}$

\section{REFERENCES}

1) M. H. Breese: Pestic. Sci. 8, 264 (1977)

2) C. N. E. Ruscoe: Pestic. Sci. 8, 236 (1977)

3) E. Barlow, A. B. Hadaway, L. S. Flower, J. E. H. Grose \& C. R. Turner: Pestic. Sci. 8, 291 (1977)

4) M. Elliott, A. W. Farnham, N. F. Janes \& D. M. Soderlund: Pestic. Sci. 9, 112 (1978)

5) N. Mikami, K. Furuzawa, Y. Baba, H. Yamada \& J. Miyamoto: unpublished observation (1984)

6) A. N. Wright, T. R. Roberts, A. J. Dutton \& M. V. Doig: Pestic. Biochem. Physiol. 13, 71 (1980)

7) A. J. Dutton \& T. R. Roberts: unpublished observation (1978) 
8) N. Mikami, S. Sakata, H. Yamada \& J. Miyamoto: unpublished observation (1984)

9) T. R. Roberts \& M. E. Standen: Pestic. Sci. 8, 305 (1977)

10) T. R. Roberts \& M. E. Standen: Pestic. Sci. 12, 285 (1981)

11) R. A. Chapman, C. M. Tu, C. R. Harris \& C. Cole: Bull. Environ. Contam. Toxicol. 26, 513 (1981)

12) M. J. Crawford, A. Croucher \& D. H. Hutson: J. Agric. Food Chem. 29, 130 (1981)

13) M. J. Crawford, A. Croucher \& D. H. Hutson: Pestic. Sci. 12, 399 (1981)

14) L. M. Cole, L. O. Ruzo, E. J. Wood \& J. E. Casida: J. Agric. Food Chem. 30, 631 (1982)

15) D. H. Hutson, L. C. Gaughan \& J. E. Casida: Pestic. Sci. 12, 385 (1981)

16) D. H. Hutson \& J. E. Casida: Xenobiotica 8 , 565 (1978)

17) H. Kanamaru, M. Okuno, K. Kawahara, I. Nakatsuka \& A. Yoshitake: unpublished observation (1984)

18) N. Mikami, N. Takahashi, K. Hayashi \& J. Miyamoto: J. Pesticide Sci. 5, 225 (1980)

19) C. S. Helling \& B. C. Turner: Science 162 562 (1968)

20) G. G. Guilbault \& D. N. Kramer: Anal. Chem. 38, 834 (1966)

21) EPA, Guidelines for registering pesticide in the United States: Fed. Regist. 40, 26802 (1975)

22) N. Takahashi, N. Mikami, H. Yamada \& J. Miyamoto: unpublished observation (1984)

23) W. M. Draper \& D. G. Crosby: J. Agric. Food Chem. 29, 699 (1981)

24 R. G. Ross: Ph. D. Thesis, Univ. of California, Davis, Calif. (1974)

25) R. G. Zepp, N. L. Wolfe, J. A. Gordon \& R. C. Fincher: J. Agric. Food Chem. 24, 727 (1976)

26) N. Takahashi, N. Mikami, T. Matsuda \& J. Miyamoto: J. Pesticide Sci. 10, 643 (1985)

27) J. Miyamoto \& N. Mikami: "Pesticide Chemistry: Human Welfare and the Environment," ed. by J. Miyamoto \& P. C. Kearney, Vol. II, Pergamon Press, Oxford, pp. 193-200, 1983

28) L. O. Luzo, R. L. Holmstead \& J. E. Casida: J. Agric. Food Chem. 25, 1385 (1977)

29) Y.-L. Chen \& J. E. Casida: J. Agric. Food Chem. 17, 208 (1969)

30) N. Takahashi, N. Mikami \& J. Miyamoto: unpublished observation (1978)

31) R. L. Holmstead, D. G. Fullmer \& L. O. Ruzo: J. Agric. Food Chem. 26, 954 (1978)

32) R. L. Holmstead, J. E. Casida, L. O. Ruzo \& D. G. Fullmer: J. Agric. Food Chem. 26, 590 (1978)

33) D. A. M. Watkins: Chem. Ind. 1974, 185

34) N. Takahashi, N. Mikami, M. Kagoshima, H. Yamada \& J. Miyamoto: unpublished observation (1983)

要約

\section{ピレスロイド系殺虫剤サイパーメスリンの水中 および土壇表面における光分解}

高橋尚裕，三上信可，松田 正，宮本純之

水中の $(1 R$, cis, $\alpha R S)-$ および $(1 R$, trans, $\alpha R S)-$ サイ パーメスリンに太陽光を照射すると，cis 異性体は trans 異性体に比べ約 1.4 1.7 倍速く分解し，cis 異性体の光 分解半減期は蒸留水打よび $1 \mathrm{ppm}$ 腐植酸水中で $2.3 \sim 2.6$ 日，河川执よび海水中で $0.6 〜 0.7$ 日， $2 \%$ アセトン水中 で 0.5 日以内であった。土壌表面にお就るサイパーメス リンの光分解速度は両異性体間で有意な差はなく，3 種 類の土壤に括ける光分解半減期は 0.6 1.9日であった. サイパーメスリンは太陽光照射条件下で扣もに, シクロ プロパン環の $1 R / 1 S$ 扣よび cis/trans 異性化, エステル およびジフェニルェーテル結合の開裂， $\mathrm{CHO}$ 基の $\mathrm{COOH}$ 基への酸化, $\mathrm{CN}$ 基の $\mathrm{CONH}_{2}$ 基への水和, $\mathrm{CONH}_{2}$ 基の $\mathrm{COOH}$ 基への加水分解，八ロゲン化側鎖の酸化的開裂, 脱ハロゲン化, 分子内環化および光無機化により分解さ れた。 